\title{
Libraries as Publishers: Turning the Page?
}

\begin{abstract}
This article seeks to provide a general review of the publishing activities of some major libraries across the world. At a time when the publishing industry is experiencing profound challenges to its established business models and traditional routes to market through bookshops are under threat from online retailers such as Amazon it is timely to see how libraries are faring during this period and whether these developments are changing libraries' publishing outputs.
\end{abstract}

The publishing activities are considered in relation to the format of the titles available, how the titles are sold, the range of subjects covered in the programme and whether there are digital versions available. The numerous digital catalogues, learning materials and other online resources are considered out of scope for the purpose of this article and the focus is therefore on what we might consider 'traditional' publishing outputs.

The article considers the publishing programmes of British Library, the Bibliothèque Nationale de France, the Bodleian library, the Biblioteca Nacional do Brasil, the State Library of Victoria and the National Library of Australia.

Keywords: library publishing, books, bookstores, exhibitions, catalogues

\section{Introduction}

This article seeks to provide an overview of the publishing activities of some national and major libraries from across the world. At a time when the publishing industry is experiencing profound challenges to its established business models and the traditional divisions between libraries, publishers and booksellers are becoming more fluid it is timely to see how libraries are faring and to what extent - if at all - these seismic developments are changing libraries' publishing outputs.

Although the published output of major libraries is multifarious this article will focus on what we might consider conventional publishing outputs principally the book in print or electronic 
format, audio products and exhibition catalogues. The production of current bibliographies and financial accounts, annual reports and so on are therefore excluded as are other digital products and services, such as online galleries, educational resources and digital collections. These resources might arguably be considered publishing outputs but for the purpose of this article they are out of scope.

Through a content analysis of library websites the article reviews the publishing programmes of the British Library, the Bibliothèque Nationale de France, the Bodleian library, the Biblioteca Nacional do Brasil, the State Library of Victoria and the National Library of Australia. The libraries selected are discussed in the context of the following issues:

- whether there is an 'active' publishing programme in the library

- the subject range of books published including exhibition catalogues

- the sales channels available to obtain these books (the library store, availability through online retailers and conventional book retailers)

- digital access to published content

\section{Libraries as Publishers}

It is not surprising that libraries as repositories of content have sought to promote their collections through the publication of various specialist catalogues, illustrated books, monographs and exhibition guides and there is a fine tradition of publishing taking place by libraries, be they national, university or special. Indeed national libraries have, often by law, a requirement to produce bibliographies of publications in print or electronic format. Many libraries have a long and proud tradition of producing books, for example the Library of Congress started a publishing programme shortly after it was founded ${ }^{1}$ and the forerunner to the British Library has been active since its earliest days.

In 1983 the International Group of Publishing Libraries (IGPL) was founded as a home for major libraries that had active publishing programmes and the membership included the British Library, the Bibliothèque Nationale de France, the Library of Congress and Harvard

\footnotetext{
${ }^{1}$ Leonard Kniffel (1989). 'Glutting the market or taking up slack? Books made to order: Libraries as Publishers'. American Libraries. Vol 20 No. 8 pp 734-737.
} 
University Library amongst others. The IGPL met biennially and discussed issues of mutual concern, with the last meeting held in 2007.

Libraries and publishers have always had a symbiotic relationship with the former providing a place to access the output of the latter. However, these neat delineations are fraying as technological developments in the past decade have seen the publishing barriers to entry lowered, particularly for services such as print and distribution. This has lead to an explosion of published material as activities previously the preserve of the publishing industry are made accessible to everyone. It is no exaggeration to say we are witnessing a revolution in the way information is produced, disseminated and accessed and these developments are arguably changing the face of the information world and library business models as a consequence.

\section{The British Library}

The British Library arguably has the most active publishing programme of the world's major and national libraries and it can trace this back to 1780 when the British Museum Library first started producing catalogues based on the collections ${ }^{2}$. The current publishing programme can trace its routes back to 1981 and it now publishes approximately 40 titles a year.

Turnover is c£1 million and there are the equivalent of six full time staff employed. In the past the $\mathrm{BL}$ used to publish $\mathrm{PhD}$ theses amongst other research outputs but today the publishing programme focuses on illustrated books and audio CDs. Books are published which cover: History, Books about Books, Cartography, Religious Studies, Arts and General, Exhibition Books and finally Facsimiles. Audio CDs are produced for Arts and Literature, History and Wildlife, the latter being particularly successful. As a strategy this aligns closely with the BL core collections. The books are a mix of what are considered general 'trade' titles which have broad appeal through traditional book retail outlets and scholarly works and facsimiles of interest to an expert readership. Coverage within the series is broad; the Books about Books category in 2012 saw not only the publication of serious scholarly works such as From Compositors to Collectors: Essays on Book-Trade History but also Booklover's Book of Jokes, Quips and Quotes, a departure for the BL. Examples of out of copyright titles include The Gentleman's Art of Dressing with Economy by 'A Lounger at the Clubs' and Beauty,

\footnotetext{
${ }^{2}$ British Library Publishing. Accessed 26 May 2012
} 
what it is and how to Retain it written by 'A lady'. The crucial requirement is that it is truly profitable.

The British Library as a major cultural institution in the United Kingdom hosts several exhibitions of varying sizes throughout the year and the publishing department produces books for the two major exhibitions every year (recently the Royal Manuscripts and Writing Britain exhibitions).

The Digital Library Programme (DLP) is the BL's principal initiative to engage with the digital world. The heart of the DLP is the storage system that enables the storage, access and management of the BL's digital assets. By the end of 2011 the BL expected this digital store to include 80,000 books, 37,000 sound files, 700,000 newspapers, 26 million archived websites and 10 million e journal articles ${ }^{3}$. Although there are just a few ebooks yet available for the print titles it is reasonable to expect this rich source of content to lead to digital titles being available for sale in due course, particularly as legal deposit titles come out of copyright.

BL Publishing titles are sold through a variety of channels including the BL online shop, major high street retailers such as Waterstones, Foyles and Amazon. As a medium sized publisher the BL has a network of agents and representatives throughout the world (notably the University of Chicago Press) and the library promotes itself through attendance at the Frankfurt and London book fairs. The BL bookshop generates $25 \%$ of its sales from library publications.

\section{Bodleian Library Publishing}

Founded in 1602, the Bodleian library, as one of the six legal deposit libraries for the UK, is home to over 9 million volumes and a large number of manuscripts and rare printed books. It is the largest university library in Britain and the second largest in the country after the British Library. The Bodleian library published its first book in 1604 which was a catalogue of the library's holdings and was financed by compulsory purchase for readers. While the library continued to publish catalogues in the following centuries, the modern-day publishing

\footnotetext{
${ }^{3}$ Steve Green. (2009),"The digital library programme at the British Library: goals and priorities", Interlending \& Document Supply. Vol. 37 Iss: 3 pp. 136 - 139
} 
programme started in the mid-twentieth century, with exhibitions catalogues and picture books.

The programme was relaunched in 2004 and today Bodleian Library Publishing produces 18 titles per annum and the publishers intend to increase this to 20-25 books pa. Publishing output covers 'trade and scholarly books on a wide range of subjects drawn from or related to the Library's rich collection of rare books, manuscripts, maps, postcards and other ephemera' ${ }^{4}$. Books are published in: Cartography, History, Cookery \& Food, Oxford, Facsimiles, Exhibition Catalogues, Library Catalogues, Picture books (although the most recent was published in 1992) and a small Treasures series of highly illustrated books.

Like the British Library the Bodleian publishes a rich mix of scholarly and more general interest titles, for example How to Woo, When, and to Whom was a 2006 title originally published in 1855 .

No ebooks are produced at the moment but there are plans to do so in the future. Bodleian Library titles are available to buy through the online shop, mail order, high street book stores and the Bodleian Library Shop in Oxford. Like the British Library, the Bodleian co-publishes titles, sells rights worldwide and exhibits and the London and Frankfurt book fairs.

\section{Bibliothèque Nationale de France}

The BnF's publishing division, Editions de la Bibliothèque Nationale de France is a medium sized publisher with approximately 1000 titles in print. The publishing strategy has two broad aims; first a public service mission to fulfill the scientific mission of the library and second, the publication of art books and exhibition books for a wider audience which are sold through bookshops and the BnF online store.

In the scholarly field the primary publishing outputs are scientific reference publications for researchers and library professionals which reflect the library's various specialist collections and expertise. Many of these publications have won awards in previous years.

\footnotetext{
${ }^{4}$ Bodleian Library Publishing. Accessed 29 May 2012
} 
The BnF publishes illustrated books that accompany major exhibitions organized by the library. These books are published in French for a wide audience and cover not just the items exhibited but include additional texts and artworks to give some background to the exhibition and the artists. Titles are often produced with partner publishers or museums. Recent titles include Henri Rivière - Between Impressionism and Japonisme (2009) and Qumran - The secret of Dead Sea Scrolls (2010). In 2012 exhibition books include Joel-Peter Witkin: Heaven or Hell an illustrated co-edition published by the $\mathrm{BnF}$ and publisher La Martinière and Spotlight on the Press: From the Gazette to the Internet an Editions BnF illustrated work based on the exhibition at the library from April to July 2012. As a national library the BnF publishes descriptive catalogues of its ancient and specialized collections, such as the Hebrew Manuscripts Library of France and catalogues of illustrated manuscripts.

Scientific books, conference proceedings and exhibition catalogues are available to download through Gallica, the BnF's digital library with prices ranging from free to E20 and content accessible in .pdf and HTML formats. Editions BnF titles are made widely available can be bought through the library's online shop, Amazon.fr, partner publisher websites and major bookshops.

\section{The Biblioteca Nacional do Brasil}

Brazil's national library, the Biblioteca Nacional do Brasil is based in Rio de Janeiro and houses 9 million items and is considered by UNESCO to be one of the 10 largest national libraries in the world. Despite the size of the population and its rich history Brazil has a somewhat bookless past which must be understood in relation to the colonial period when under Portuguese rule (1500-1822) the printing of books and periodicals was forbidden and as a consequence the first book in the country was only published in $1808^{5}$.

In 1990 the library became a foundation (Fundação Biblioteca Nacional - FBN) operating under the auspices of the Ministry of Culture. In addition to being the legal depository in Brazil and running the ISBN agency the library acquired specific responsibilities not only for

\footnotetext{
${ }^{5}$ Margaret Adolphus. Focus on libraries in Brazil. Emerald Group Publishing. http://www.emeraldinsight.com/librarians/management/viewpoints/brazil.htm?part=1. Accessed 1 June 2012.
} 
the production and transfer of knowledge relating to its collections but also for the promotion of literacy and reading.

Today the library publishes not only the current Brazilian bibliography but a series of other publications too. Major exhibitions are accompanied by highly illustrated books published by the library and recent titles include Biblioteca Nacional 200 Anos (2010) and another on the Brazilian playwright and poet Machado de Assis published in 2009. There is a small series of facsimilies and print catalogues are produced around major collections such as Dom Joao and the National Library: A Legacy in Letters (2009). All books are available to buy through the library online shop. No ebooks are available but this is no surprise in a country where ebooks make up less than $0.5 \%$ of the market although with Amazon planning to launch its Kindle in the country in 2012 we should expect the figure to rise in due course ${ }^{6}$.

In addition to its own publishing programme the library promotes reading and research through two publishing projects of relevance to this article.

The first of these relates to the publication of books and monographs to stimulate scholarly research based around the library's collections. Under this scheme editors are awarded grants to publish books written by Brazilian authors. Funding is assisted by private backers.

The second project relates to the library's 'Program for Supporting the Translation and Publishing of Brazilian Authors Abroad'. The stated aim of this project is 'to foster a greater presence of works of local (Brazilian) literature in foreign publishing company's catalogues and in bookstore shelves and virtual bookshelves throughout the world'. Financial help in the form of grants is made available to foreign publishers who wish to publish BrazilianPortuguese works from all genres including romance, short stories, poetry, reference works, children's and, literary and historic essays. The project started in 2011 with 68 different books published in 18 countries, including Spain, Germany, England, France, Italy, the United States, Argentina, Mexico, Israel and Croatia. Grants range in size from US\$2,000 to US $\$ 8,000$ and the foreign publisher must publish at least 1000 copies of the work within 18

\footnotetext{
${ }^{6}$ http://publishnewsbrazil.com/2011/08/brazil-ebook-market-slow-progress. Accessed 1 June 2012.
} 
months of signing the contract. The library has confirmed funding will continue until at least $2020^{7}$.

The contract requires the publisher to include the following reference in the copyright page of the book in Portuguese and in the language of translation: "Obra publicada com o apoio do Ministério da Cultura do Brasil / Fundação Biblioteca Nacional” (Work published with the help of the Brazilian Ministry of Culture and National Library Foundation) and include the Foundation's logotype ${ }^{8}$.

\begin{tabular}{|cc|}
\hline & $\begin{array}{c}\text { PROGRAMSBUDGET } \\
2011 / 2020\end{array}$ \\
\hline 2011 & USS $635,000.00$ \\
2012 & US\$ $698,000.00$ \\
2013 & US\$ $698,000.00$ \\
2014 & US\$ $730,000.00$ \\
\hline 2015 & US\$ $730,000.00$ \\
2016 & US\$ $761,000.00$ \\
\hline 2017 & US\$ $793,000.00$ \\
\hline 2018 & US\$ $825,000.00$ \\
\hline 2019 & US\$ $857,000.00$ \\
\hline 2020 & US\$ $888,000.00$ \\
\hline TOTAL & US $\$ 7,615,000.00$ \\
\hline
\end{tabular}

Figure 1. Program for Supporting the Translation and Publishing of Brazilian Authors Abroad budget 2011-2020

\section{State Library of Victoria}

The State Library of Victoria co-publishes hardback and paperback books that draw on the library's diverse collections. The subjects cover a range of subjects including the history of book design, children's literature and contemporary documentary photography. All the books

\footnotetext{
${ }^{7}$ http://publishingperspectives.com/2011/07/brazil-commits-internationalization-brazilian-literature. Accessed 1 June 2012.

${ }^{8}$ http://www.bn.br/portal/arquivos/pdf/translation-grant-fbn-minc-2011.pdf. Accessed 1 June 2012.
} 
are highly illustrated and feature items from the collections such as maps, pictures, manuscripts and letters.

The library works with a range of external publishers as shown by some recent titles: Love and devotion: from Persia and beyond (2012) published by Macmillan Art Publishing in association with the State Library of Victoria and the Bodleian Library and produced to coincide with the exhibitions in Melbourne and Oxford, The garden of ideas: four centuries of Australian style published with the Miegunyah Press and Detective Piggott's casebook: true tales of murder, madness and the rise of forensic science which was published with Hardie Grant Books.

Books are sold through a variety of channels. The library has a close link with the independent bookseller Readings and titles can be bought in its bookstore in the library and through its website readings.com.au which lists 29 SLV titles. Titles are also available through Amazon.com and some Australian online booksellers including Booktopia. The library makes some ebooks available for remote access to residents of Victoria state.

\section{National Library of Australia}

The NLA in Canberra has a publishing programme that aims to 'demonstrate our prominence in Australia's cultural, intellectual and social life and to foster an understanding and enjoyment of the National Library and its collections, we will selectively interpret and highlight the Library's collections through publications, exhibitions and events'. 9

A broad range of illustrated and narrative books are published for adults and children which showcase the library's collections. Recent titles include: A Banksia album: two hundred years of botanical art and a children's book These are My Hands / These are My Feet which is described as 'colourful and fun lessons of discovery'. Titles for publication are decided by the NLA Publications committee which ensures titles align with the corporate mission.

All NLA Publishing books are available through the library bookshop (and its online store which lists 187 NLA titles) and various other online outlets.

\footnotetext{
${ }^{9}$ http://www.nla.gov.au/policy-and-planning/publications-policy. Accessed 5 June 2012.
} 
The NLA has decided to make some ebooks available for download for free in .pdf format. These cover all subjects and are titles previously published in print form over many years. A typical example is Eyes to the Future a title which explores the social custom and encounters with Australia's neighbours which was originally published in print form in 2000 and is now made freely available online. The value of some of these low quality images may make one question the ultimate value of this as a resource, however.

\section{Conclusion}

Publishing in libraries is not only surviving but thriving in certain countries where good books can still be produced that showcase the collections of the library and accompany exhibitions and shows. Whether and how these often highly illustrated books can be reproduced digitally remains to be seen. From a publisher's perspective many of these print books are bought to be seen and admired and publishers will always need to consider the cost of digital conversion and whether they are likely to make a return on this investment. So often in publishing we see technologies in search of a market and books produced by libraries may survive in print form for some time yet. A further article exploring digital publishing initiatives in libraries would be of great interest to publishers and libraries alike.

It is perhaps appropriate to end with a quote by the Cambridge sociologist John Thompson who observes that 'It's become easier to publish but harder to sell' ${ }^{10}$. This is undoubtedly true but many major libraries would appear to be bearing up well in these turbulent times.

\section{REFERENCES}

http://publishing.bl.uk/

http://editions.bnf.fr

http://www.bn.br/portal/?nu_pagina=110

http://www.slv.vic.gov.au/explore/our-publications

http://www.nla.gov.au/publications\#getpub

http://www.bodleianbookshop.co.uk/about_us.asp?TAG=\&CID

\footnotetext{
${ }^{10}$ John Thompson. (2010). Merchants of Culture. Polity Press. Cambridge.
} 
